Article

\title{
Equivalent Cement Clinker Obtained by Indirect Mechanosynthesis Process
}

\author{
Rabah Hamzaoui * (D) and Othmane Bouchenafa * \\ Institut de Recherche en Constructibilité IRC, ESTP, Université Paris-Est, 28 Avenue du Président Wilson, \\ 94234 Cachan, France \\ * Correspondence: rhamzaoui@estp-paris.eu (R.H.); obouchenafa@estp-paris.eu (O.B.); Tel.: +33149080334 (R.H.); \\ +33149082327 (O.B.)
}

Received: 23 September 2020; Accepted: 6 November 2020; Published: 9 November 2020

check for updates

\begin{abstract}
The aim of this work is to study the heat treatment effect, milling time effect and indirect mechanosynthesis effect on the structure of the mixture limestone/clay (kaolinite). Indirect mechanosynthesis is a process that combines between mechanical activation and heat treatment at $900{ }^{\circ} \mathrm{C}$. XRD, TGA, FTIR and particle size distribution analysis and SEM micrograph are used in order to follow thermal properties and structural modification changes that occur. It is shown that the indirect mechanosynthesis process allows the formation of the equivalent clinker in powder with the main constituents of the clinker (Alite $C_{3} S$, belite $C_{2} S$, tricalcium aluminate $C_{3} A$ and tetracalcium aluminoferrite $\mathrm{C}_{4} \mathrm{AF}$ ) at $900^{\circ} \mathrm{C}$, whereas, these constituents in the conventional clinker are obtained at $1450{ }^{\circ} \mathrm{C}$.
\end{abstract}

Keywords: cement clinker; clinkerization; indirect mechanosynthesis; nanostructured materials; crystalline structures

\section{Introduction}

Portland cement is manufactured from raw material obtained by mixing and grinding limestone and minerals rich in silica and alumina (clay or kaolin) and other additives. This mixture is then calcined at $1450{ }^{\circ} \mathrm{C}$ to obtain the clinker. The clinker is finely crushed and blended with a source of sulfate (gypsum or anhydrite) and other minerals to form the cement [1].

However, the production of cement is responsible for high energy consumption. For example, in 2014, the cement manufacturer was the third largest industrial energy consumer ( $7 \%$ of the global industrial energy equivalent to 10.7 exajoules) and the second largest quota of total direct industrial $\mathrm{CO}_{2}$ emissions (27\% equivalent to 2.2 gigatons per year) [2].

To respond to the demand for cement and at the same time avoid damaging more of the planet, it is necessary to find solutions to decrease energy consumption and $\mathrm{CO}_{2}$ emission by the clinkerization process. Many solutions were proposed by scientists such as energy efficiency and alternative fuels [2-5], carbon capture and storage (CCS) [2,3], the substitution of clinker by coproducts [6-11], and the substitution of clinker by the activated mineral additions (kaolinite, fly ashes, and slag) carried out by mechanosynthesis [12-14].

Mechanosynthesis is described as a high-energy milling process using a ball and/or rod as milling tools [15-19]. In general, mechanosynthesis is defined as a ball milling process, in which the powder mixture is placed with balls in a container, subjecting powders to high-energy collisions provoked by the balls. Mechanosynthesis is characterized by the repetitive welding/fracturing (collage/decollage) movement of the powder mixture. This movement allows one to obtain metastable crystalline or nanocrystalline phases, and to transform crystalline phases into amorphous phases. Nanocrystalline materials obtained by mechanosynthesis have been the subject of much research over the past two 
decades. As their name suggests, they are single-phase or multiphase polycrystals with a grain (crystallite) size at the nanoscale $(1-100 \mathrm{~nm})$. Half of the material by volume consists of grain joints or interphases [20-24].

Mechanosynthesis makes it possible to reduce the size and combine solids from the micrometer scale of a powder particle, while crystallites (the grains forming a particle) are reduced to a nanometric size, resulting in nanostructured materials.

The mechanosynthesis process can be divided into three steps: in the first step, the particles rearrange and stack, the particles slide over each other with a minimum of deformation and fractures, which leads to a particle size reduction and a particle shape change. In the second step, elastic and plastic deformations are applied to the particles. During this phase, the phenomenon of cold welding is most commonly observed, which has the effect of increasing the size of the powder particles due to their agglomeration. In the last step, the particles are fractured, resulting in additional deformation and/or fragmentation of the particles, resulting in a reduction in particle size [20-24].

Mechanosynthesis was firstly used in the 1970s by John Benjamin to produce nickel and iron-based superalloys by oxide dispersion strengthened (ODS) for aerospace applications [25]. Thereafter, the mechanosynthesis process has been developed and enhanced over time.

Three mechanosynthesis processes can be distinguished [26]. The first process is called direct mechanosynthesis, which consists of mechanically activating one or more powders for a fixed period (short or long milling) until the finished product is obtained $[12-15,18,19]$. The ODS process is part of the direct mechanosynthesis [25].

The second process is called indirect mechanosynthesis, a technique that combines mechanical activation usually for a short milling time followed by another process. Comparatively to mechanically activated annealing (M2A) [27,28], mechanically activated sintering (MAS) [29,30] and mechanical activation of self-heat-sustaining reaction (MASHS) can be used [31].

The third process is called mechanochemistry, which refers to any process that uses grinding to initiate chemical reactions. The mechanochemistry applications encompass all provoked chemical reactions by a mechanical activation, such as exchange reactions, reduction/oxidation reactions, compounds decomposition, and phase transformations. Mechanochemistry can be considered as a direct mechanosynthesis $[13,32]$ or indirect mechanosynthesis process $[33,34]$.

This work aims to propose an indirect mechanosynthesis process with the purpose of producing an equivalent clinker with a low heat temperature $\left(<1000^{\circ} \mathrm{C}\right)$. In this process, less fossil energy (coke or fuel, etc.) is used in industrial furnaces. However, more electric energy is used due to high energy milling. This energy can be considered to be less polluting, especially if it is from a renewable or nuclear origin. In addition, it should be noted that the study of energy consumption and $\mathrm{CO}_{2}$ emission concerning indirect mechanosynthesis is under investigation and will be soon published.

The process of indirect mechanosynthesis begins with the mechanical activation of the limestone and clay mixture and is followed by heating it for $1 \mathrm{~h}$. Firstly, the study of the temperature effect on the structure of the limestone/clay (kaolinite) mixture at different temperature treatments $(400,600$, and $900{ }^{\circ} \mathrm{C}$ ) is carried out. In addition, the milling time effect $(5,10,15$, and $60 \mathrm{~min})$ on the structure of limestone/kaolinite mixture is investigated. Finally, the combination of these two techniques (milling and heating) is effectuated in order to obtain the equivalent clinker.

\section{Materials and Methods}

\subsection{Raw Materials and Classic Clinker}

The limestone used for this research is supplied by OMYA ${ }^{\circledR}$ (Nièvre, France). It is constituted of $>97 \%$ of calcium carbonate $\left(\mathrm{CaCO}_{3}\right)$ in a calcite structure. The clay used in this work is Proclay ${ }^{\circledR}$ kaolinite produced in the Beaujard site (Poigny, France); it is formed of kaolinite and quartz. Loss on ignition (LOI) of the mixture $(\mathrm{LS} / \mathrm{C})$ is $40 \%$ and the ratio $\left(\mathrm{CaO} / \mathrm{SiO}_{2}\right)$ is 3.15 . 
For a classic clinker, an industrial clinker from VICAT company (Créchy, France) produced by the current process (thermal clinkerization) is used as a comparison to the equivalent clinker.

The chemical compositions of raw materials and conventional clinkers are investigated by $\mathrm{X}$-ray fluorescence; the results are shown in Table 1.

Table 1. Chemical composition of the raw materials and classic clinker.

\begin{tabular}{cccc}
\hline Oxide & Limestone & Kaolinite & Clinker \\
\hline $\mathrm{CaO}$ & 96.79 & 0.50 & 71.85 \\
$\mathrm{SiO}_{2}$ & 0.97 & 69.37 & 14.66 \\
$\mathrm{Al}_{2} \mathrm{O}_{3}$ & 0.63 & 24.08 & 3.02 \\
$\mathrm{FeO}_{3}$ & 0.22 & 1.54 & 3.97 \\
$\mathrm{Na}_{2} \mathrm{O}$ & - & - & - \\
$\mathrm{SO}_{3}$ & 0.14 & 0.30 & 2.26 \\
$\mathrm{MnO}$ & 0.08 & - & - \\
$\mathrm{SrO}$ & 0.21 & - & 0.28 \\
$\mathrm{TiO}$ & - & 3.52 & 0.27 \\
$\mathrm{P}_{2} \mathrm{O} 5$ & - & 0.72 & 0.24 \\
$\mathrm{MgO}$ & 0.50 & 0.60 & 1.80 \\
$\mathrm{~K}_{2} \mathrm{O}$ & 0.16 & - & 1.3 \\
$\mathrm{Others}$ & 0.42 & 1.09 & 0.35 \\
\hline
\end{tabular}

\subsection{Methods}

\subsubsection{Indirect Mechanosynthesis for the Equivalent Clinker Production}

Two processes are used to produce clinker: a high energy ball milling (mechanical activation) and heat treatment.

Mechanical activation is achieved by using a planetary ball mill (PM 400, RETSCH, Haan, Germany) for the high energy ball milling (see Figure 1). The device consists of four vials mounted on a planar disc. When the disc rotates, the vials move in a circle and in the reverse direction to the disc. The ball/powder weight ratio applied is 4 .

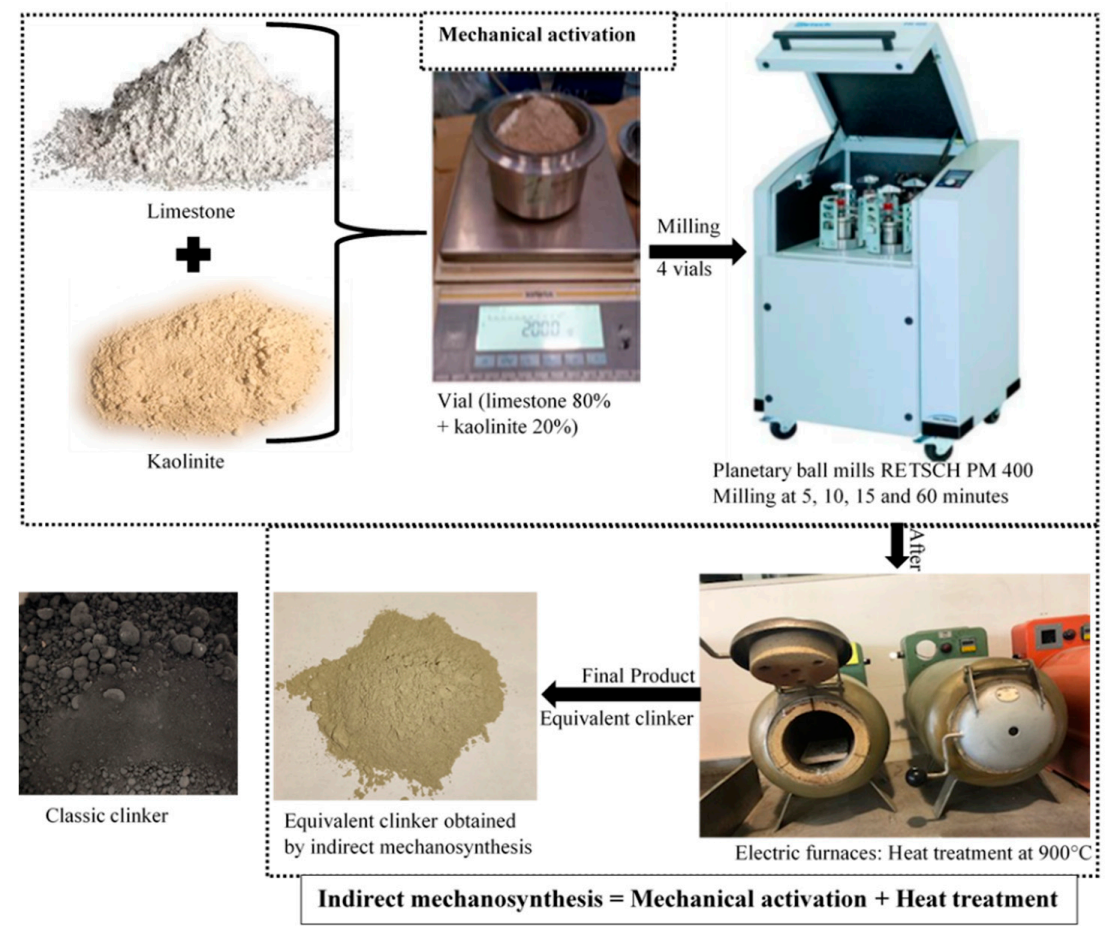

Figure 1. Representative schematic of indirect mechanosynthesis. 
To prepare the equivalent clinker, $80 \%$ of limestone (LS) (160 g) and $20 \%$ clay (C) (40 g) are put in the vial. In this process, steel balls with a diameter of $30 \mathrm{~mm}$ and a steel bottle with a capacity of $500 \mathrm{~mL}$ are used. To avoid contamination, the vials are well closed. The rotational speed of the disc and the vials are $\Omega=400 \mathrm{rpm}$ and $\omega=800 \mathrm{rpm}$, respectively. Different milling times are achieved, between 5 and $60 \mathrm{~min}$. For the thermic process, several temperatures ranging from $400{ }^{\circ} \mathrm{C}$ to $900{ }^{\circ} \mathrm{C}$ are applied for $60 \mathrm{~min}$ using an industrial electric furnace (Solo Swiss SA, Porrentruy, Switzerland) (see Figure 1).

\subsubsection{Characterization of Powders}

The chemical composition of all materials is determined by an elemental analysis performed by a Bruker S2 RANGER (XRF, BRUKER, Karlsruhe, Germany). For the structural investigation, Bruker D2 PHASER diffractometer (BRUKER, Karlsruhe, Germany) with a continuous scanning mode and $\mathrm{CuK} \alpha$ radiation $(\lambda=0.1541 \mathrm{~nm})$ is used. The parameters of the XRD analysis were: $2 \theta$ range of $5-70^{\circ}$, an increment of $0.02^{\circ}$ for $0.15 \mathrm{~s}$. For the evaluation of the X-ray diffraction pattern, the software DIFFRAC.EVA (BRUKER, Karlsruhe, Germany) with ICDD PDF2 (Newtown Square, PA, USA) is used. Winnel software is used for X-ray patterns fitting to calculate the lattice parameter changes. This fitting takes into account the shift of the high-angle diffraction line for all X-ray patterns using Bragg's law, Equation (1):

$$
2 \mathrm{~d} \operatorname{Sin}(\theta)=\mathrm{n} \lambda
$$

where (d): the distance between the planes in the atomic lattice; $(\theta)$ : the angle between the incident ray and the scattering planes; $(n)$ : an integer determined by the order given $(n=1) ;(\lambda)$ : wavelength of the incident wave. The average lattice parameter (a) is determined for all $\mathrm{X}$-ray patterns from different angles at lines (200), (220), and (201) of the calcium oxide structure by using Equation (2):

$$
d=\sqrt{\frac{a^{2}}{h^{2}+k^{2}+l^{2}}}
$$

where (hkl) are Miller indices associated to different angles; (a) is lattice parameters. The accuracy of the above expressions is evaluated by applying the standard deviation to all lattice parameters. The analysis of all X-ray patterns indicates that the precision of the lattice parameter evaluation is less than $1 \times 10^{-4} \mathrm{~nm}$.

Using the XRD profile analysis, we calculated the crystallite size (D) and the lattice strain by the Williamson-Hall method [35], as shown in Equation (3):

$$
\beta=2 \varepsilon \tan (\theta)+\frac{0.9 \lambda}{\mathrm{D} \cos (\theta)}
$$

where ( $\beta$ ) represents the full width at half maximum (FWHM) obtained with Winnel software; $(\theta)$ is the Bragg's angle; $(\lambda)$ is the X-ray radiation wavelength; $(\varepsilon)$ is the effective lattice strain; (D) is the average crystallite size. Equation (4) can be rearranged as:

$$
\beta \cos (\theta)=2 \varepsilon \sin (\theta)+\frac{0.9 \lambda}{\mathrm{D}}
$$

For all peaks of the same structure, the plot of $\beta \cos (\theta)$ of each peak versus $\sin (\theta)$ of each peak is achieved and a straight line is obtained. The straight-line intercept represents $(0.9 \lambda) / \mathrm{D}$ and the straight-line slope represents $2 \varepsilon$. From these, the crystallite size $\mathrm{D}$ and lattice strain $\varepsilon$ are evaluated.

To determine thermal behavior, TG analysis by a TGA/DSC 2 instrument (Mettler-Toledo, Viroflay, France) with a heating speed of $20^{\circ} \mathrm{C} / \mathrm{min}$ beginning from $25^{\circ} \mathrm{C}$ to $1000{ }^{\circ} \mathrm{C}$ is accomplished. To prevent contaminating the sample with the environment, nitrogen is used as purge gas $(40 \mathrm{~mL} / \mathrm{min})$.

FTIR spectroscopy is performed by a Nicolet IS10 instrument (Thermo Scientific, Waltham, MA, USA), with a Smart iTR accessory (with Diamond Plate, Thermo Scientific, Waltham, MA, USA). 
With an ATR (attenuated total reflectance) accessory, FTIR spectroscopy can examine solids, liquids, pastes, and gels. The results are evaluated using Omnic software (v2.0, Thermo Scientific, Waltham, MA, USA).

The particle size distributions are measured with a granulometer laser LS 13320 XR from BECKMAN COULTER (Villepinte, France). Liquid sample dispersion method with a size distribution between 0.01 and $2000 \mu \mathrm{m}$ is used.

In this study, the liquid used was ethanol to prevent the hydration of the samples studied. The liquid sample dispersion method is coupled with its enhanced PIDS (polarization intensity differential scattering) technology and a wide measuring range offering higher resolution, greater accuracy and reproducible results. For the dispersion of the particles, soundwaves to break up aggregates are used and a few milligrams of product in a volume of ethanol are put and agitated for at least 2 min with a magnetic agitator.

The morphology of unground powders and clinker powders A and B is analyzed by a scanning electron microscopy (SEM) S-3400 (HITACHI, Ibaraki, Japan) with an energy-dispersive spectrometer (EDS) (HITACHI, Ibaraki, Japan).

\section{Results and Discussions}

The results of this work are presented in three parts, the first of which concerns the heat treatment effect on the limestone/kaolinite mixture. The second part shows the milling time effect of direct mechanosynthesis on the limestone/kaolinite mixture. The third part discusses the indirect mechanosynthesis effect on this mixture. In this part, the formation of the equivalent clinker is obtained.

\subsection{Heat Treatment Effect on LS/C Mixture}

Figure 2 presents the XRD patterns of the untreated limestone/clay mixture (LS/C) and (LS/C) treated at 400,600 and $900^{\circ} \mathrm{C}$. For the untreated (LS/C) mixture, the presence of crystalized rhomboidric calcite (PDF\#01-083-1762) is observed. In addition, triclinic kaolinite (PDF\#00-003-0058) and hexagonal quartz (PDF\#00-046-1045) are found.

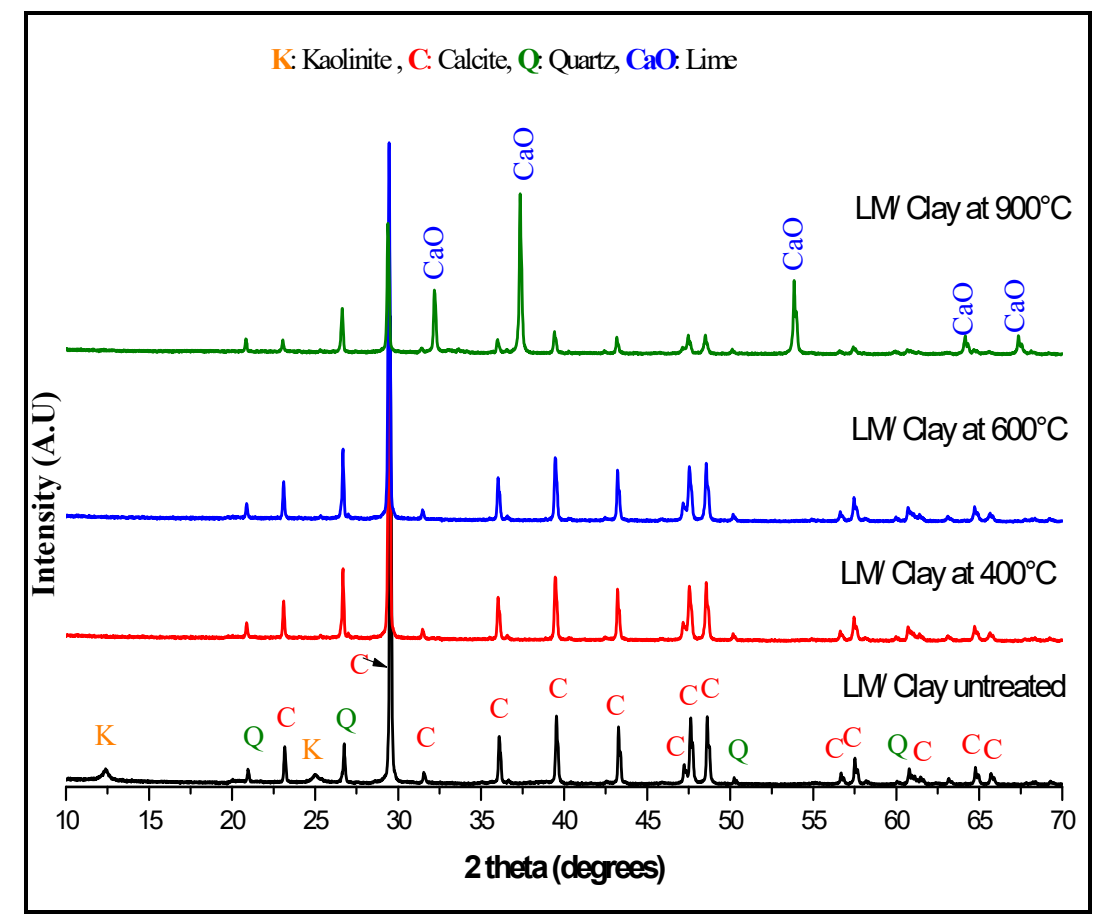

Figure 2. X-ray diffraction patterns of untreated limestone/clay mixture and heat-treated mixture at different temperature. 
Concerning the patterns of the heat-treated (LS/C) mixture, it is remarked the disappearance of all kaolinite peaks up to a temperature of $400{ }^{\circ} \mathrm{C}$. This structure modification can be due to the dehydroxylation of kaolinite according to the following formula (5) and the formation of the amorphous metakaolinite structure $\mathrm{Al}_{2} \mathrm{O}_{3} \cdot 2 \mathrm{SiO}_{2}[15,35-37]$ :

$$
\mathrm{Al}_{2} \mathrm{Si}_{2} \mathrm{O}_{5}(\mathrm{OH})_{4} \rightarrow \mathrm{Al}_{2} \mathrm{O}_{3} \cdot 2 \mathrm{SiO}_{2}+2 \mathrm{H}_{2} \mathrm{O}
$$

During heating, kaolinite starts to lose water at about $400^{\circ} \mathrm{C}$, and dehydration is almost complete at about $525^{\circ} \mathrm{C}$ [35]. Kaolinite dehydration depends on particle size, crystallinity, and purity [13,35,36].

Concerning limestone, it has been found that heat treatment has provoked partial decomposition resulting in the decaying of calcite peaks as function of a heat treatment of 400,600 and $900{ }^{\circ} \mathrm{C}$. These decaying peaks appeared to decrease in intensity and their tight peaks. In addition, the disappearance

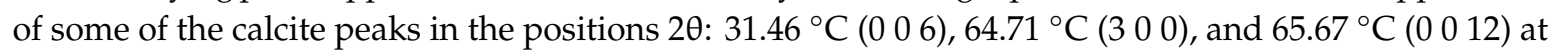
$900{ }^{\circ} \mathrm{C}$ has been remarked. The disappearance of these calcite peaks can be due to the decarbonation reaction (6) as reported by several researchers [37,38]:

$$
\mathrm{CaCO}_{3} \rightarrow \mathrm{CaO}+\mathrm{CO}_{2}
$$

This reaction produces a cubic lime (CaO) (PDF\#00-002-1088) which has been observed after a heat treatment of $900^{\circ} \mathrm{C}$. Generally, the production of lime is obtained up to $800^{\circ} \mathrm{C}$ [37-39]. From these observations of $\mathrm{CaO}$ formation, a temperature of $900^{\circ} \mathrm{C}$ for the thermal treatments for the clinkerization process by indirect mechanosynthesis is chosen. To confirm different decompositions obtained by heat treatment, TG (thermogravimetry) and DTG (derivative thermogravimetry) analyses are performed in the temperature range $25-1000{ }^{\circ} \mathrm{C}$ for the thermal behavior of the mixture (LS/C) and shown in Figure 3.

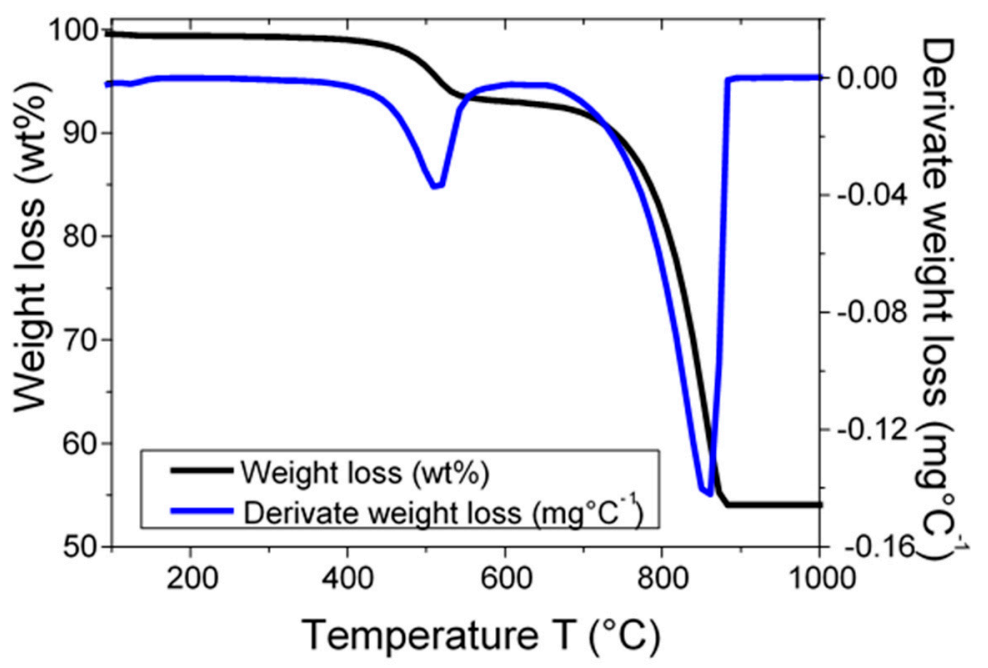

Figure 3. TG (thermogravimetry) and DTG (derivative thermogravimetry) curves of limestone/clay (LS/C) mixtures.

TG analysis suggests two weight loss regions where the first region of decomposition is bounded between $395^{\circ} \mathrm{C}$ and $580{ }^{\circ} \mathrm{C}$, attributed to the dehydroxylation of kaolinite. The second decomposition stage is between $680^{\circ} \mathrm{C}$ and $895^{\circ} \mathrm{C}$ and is attributed to the decomposition of calcite. The DTG analysis shows the presence of two peaks at $520^{\circ} \mathrm{C}$ and $861{ }^{\circ} \mathrm{C}$. To analyze the structural changes induced by heat treatment, the evolution of the crystallite size (D) and the lattice strain $(\varepsilon)$ as a function of the heat treatment temperature for both quartz and calcite are shown in Figure $4 a, b$. Both quantities are given by the instrumental width of the X-ray diffraction peaks. 


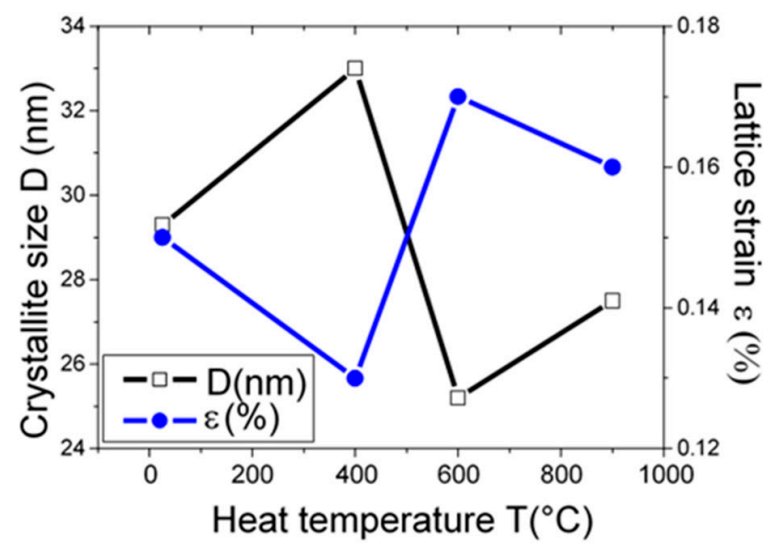

(a)

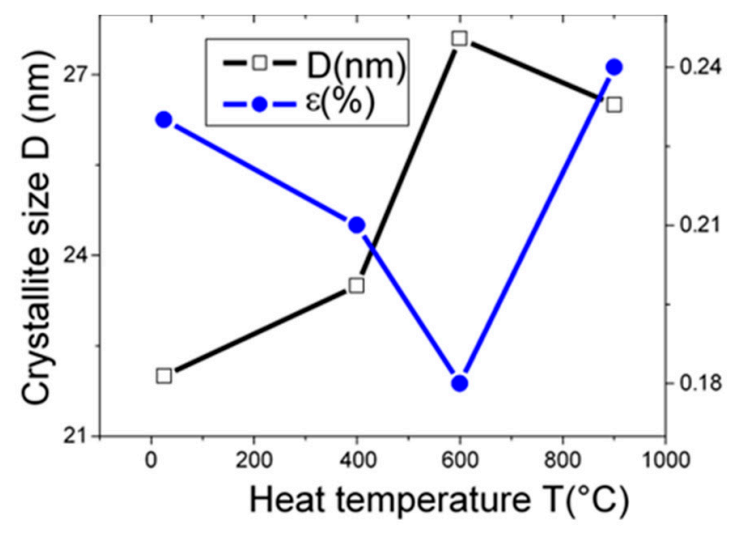

(b)

Figure 4. Crystallite size and lattice strain evolution as function of heat temperature: (a) quartz, (b) calcite.

Concerning the evolution of the quartz structure (Figure 4a), it is observed that the increase in the crystallite sizes is accompanied by the reduction in the lattice strain level when the temperature of heat treatment increases to $400{ }^{\circ} \mathrm{C}$. The value of crystallite size (D) increases from $\mathrm{D}=29.3 \pm 1.1 \mathrm{~nm}$ to $33 \pm 1.1 \mathrm{~nm}$ for $400{ }^{\circ} \mathrm{C}$, decreases to $25.2 \pm 1.1 \mathrm{~nm}$ at $600{ }^{\circ} \mathrm{C}$, and has a slight increase to $27.5 \pm 1.1 \mathrm{~nm}$ for $900{ }^{\circ} \mathrm{C}$.

However, the internal strain value decreases from $0.15 \pm 0.01 \%$ to $0.13 \pm 0.01 \%$ for $400{ }^{\circ} \mathrm{C}$ and increases to $0.17 \pm 0.01 \%$ at $600{ }^{\circ} \mathrm{C}$ with a slight decrease to $0.16 \pm 0.01 \%$ when the heat temperature is up to $900{ }^{\circ} \mathrm{C}$. The increase in crystallite size with the decrease in the lattice strain at $400{ }^{\circ} \mathrm{C}$ may be due to grain expansion and relaxation of residual stress.

The variation in crystallite size and lattice deformation of the calcite structure as a function of heat temperature is presented in Figure $4 \mathrm{~b}$. It is observed that the crystallite size (D) increases from $22 \pm 1.1 \mathrm{~nm}$ at room temperature to $27.6 \pm 1.1 \mathrm{~nm}$ at $600{ }^{\circ} \mathrm{C}$ with a slight decrease to $26.5 \pm 1.1 \mathrm{~nm}$ at $900{ }^{\circ} \mathrm{C}$. Concerning the lattice strain evolution, it has been found that the lattice strain value decreases from $0.23 \pm 0.01 \%$ at room temperature to $0.18 \pm 0.01 \%$ at $600{ }^{\circ} \mathrm{C}$ and increases to $0.24 \pm 0.01 \%$ at $900{ }^{\circ} \mathrm{C}$. This increase in lattice strain at $900{ }^{\circ} \mathrm{C}$ may be attributed to the decomposition of calcite peaks in order to form $\mathrm{CaO}$ peaks by decarbonation phenomenon.

Kohobhange et al. [40] have investigated the heat treatment effect on calcium carbonate decomposition by using high-temperature X-ray powder diffraction (HT-XRD). The authors [40] have found that the low lattice strain value for calcite is recorded before thermal decomposition at $675^{\circ} \mathrm{C}$, whereas with the progressive heating at $775^{\circ} \mathrm{C}$, maximum lattice strain value is observed. The authors have attributed this increase to the strong lattice vibrations and atomic displacements over the transformation phase and decomposition from calcite structure trigonal to calcium oxide cubic structure formation. In addition, the authors have remarked that the maximum calcite crystallite size is observed at $775^{\circ} \mathrm{C}[40]$.

\subsection{Milling Time Effect on Mixture LS/C}

Figure 5 presents X-ray diffraction patterns of the milling time effect on the structure of (LS/C) mixture. 


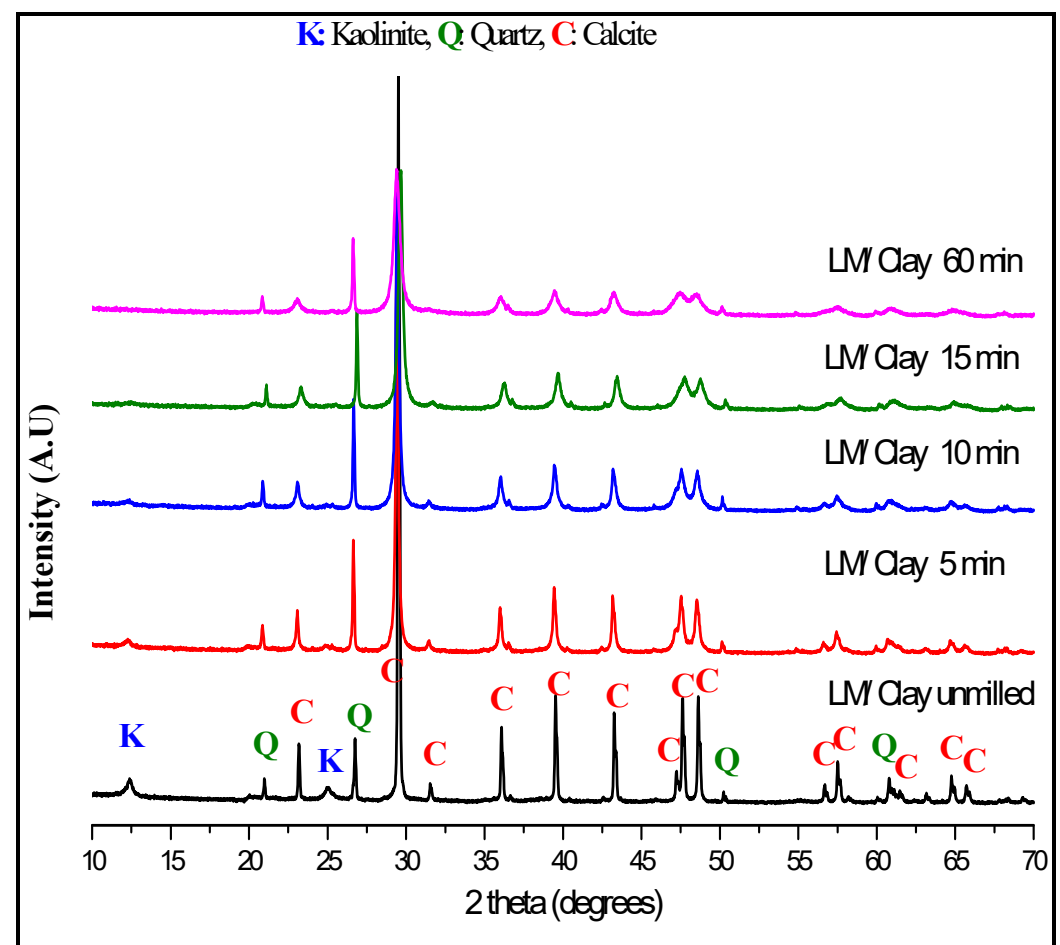

Figure 5. Diffraction patterns of a raw and milled mixture of limestone/clay for different duration.

Concerning the kaolinite structure, we found the decaying of peaks at $2 \theta=12.53^{\circ} \mathrm{K}(001)$, $2 \theta=25.17^{\circ} \mathrm{K}(002)$ for $5 \mathrm{~min}$ and $10 \mathrm{~min}$ of milling. The total disappearance of theses peaks is obtained after 15 min of milling which reaches complete amorphization. For quartz structure, we observed the peaks enlargement as function of milling time which may be due to the crystallite size reduction and formation of nanostructured quartz $[18,21,24,25]$.

Hamzaoui et al. [13] have studied the milling time effect on the structure and thermal behavior of proclay kaolinite by using a planetary ball mill. The authors have obtained an amorphous structure of kaolinite followed by nanocrystalline quartz formation after one hour of milling. The transition from the crystalline state into an amorphous state can be produced by internal strain accumulation as defects (point defects, dislocations, etc.) in the crystalline material after deformations provoked by ball milling. These defects increase the Gibbs free energy of the crystalline phase. When the high defect density in the crystalline material increases and Gibbs free energy reaches the amorphous phase level, the transition from the crystalline phase to the amorphous phase can be carried out $[16,20,24]$.

Concerning calcite peaks, it is remarked that the peak at $2 \theta=31.46^{\circ} \mathrm{C}(006)$ disappears completely after 15 min of milling. For the other calcite peaks, the reduction in their intensities, even for the most intense peak at $2 \theta=29.42{ }^{\circ} \mathrm{C}(104)$, can be observed, as well as peak enlargement as a function of the milling time increase, which suggests nanostructured calcite formation.

Figure $6 a, b$ shows the changes of the crystallite size (D) and the lattice strain $(\varepsilon)$ versus the milling time for both quartz and calcite. 


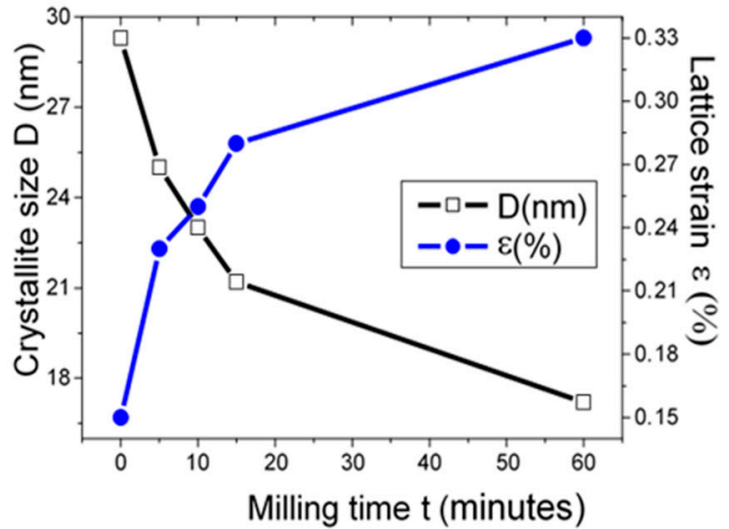

(a)

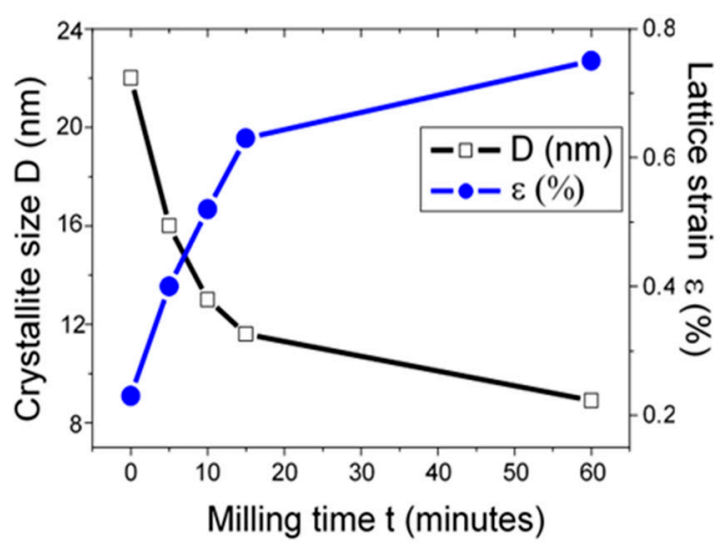

(b)

Figure 6. Crystallite size and lattice strain evolutions as function of the milling time of: (a) quartz, (b) calcite.

It is observed that the crystallite size decreases, and lattice strain increases versus milling time for both quartz and calcite structure. Concerning quartz structure (Figure 6a), it has been found that the crystallite size decreases from $29.2 \pm 1.1(\mathrm{~nm})$ to $17.2 \pm 1.1(\mathrm{~nm})$ after $60 \mathrm{~min}$ of milling. The lattice strain of quartz increases from $0.15 \pm 0.1(\%)$ to $0.33 \pm 0.1(\%)$ after 60 milling time. The decrease in crystallite size and the increase in lattice strain can be attributed to a high-energy milling process that uses balls in which powder particles are subjected to the transfer of mechanical energy to the powder particles by plastic deformation.

Kohobhange et al. [41] have studied the effect of prolonged milling until $360 \mathrm{~h}$ of conventional ball milling on modification quartz structure. The authors have remarked that, versus milling time, an increase in lattice strain and dislocation density followed by a fast decrease in crystallite size can be observed.

Figure $6 \mathrm{~b}$ presents the changes of the crystallite size and lattice strain of the calcite structure versus milling time. It is observed that crystallite size decreases from $22 \pm 1.1 \mathrm{~nm}$ to $8.9 \pm 1.1 \mathrm{~nm}$ and the lattice strain increases from $0.23 \pm 0.01(\%)$ to $0.75 \pm 0.01(\%)$ when the milling time reaches $60 \mathrm{~min}$. In comparison to heat treatment, it is observed that the lattice strain of both (quartz and calcite) is more important in the milling process. This mechanical transfer introduces strains into the powder through the dislocation generation and other defects. These defects provoke a reduction in grain sizes, generally produced as a consequence of the reduction in the diffusion distances. All these effects lead to distinct structural features that affect the final product and the blended elemental powders during the milling process. Among these properties is the formation of the nanostructured material with the stable state at room temperature.

\subsection{Indirect Mechanosynthesis and Equivalent Clinker Formation}

\subsubsection{XRD}

X-ray patterns of the (LS/C) mixture milled at a different time $(5,10,15$ and $60 \mathrm{~min})$ followed by a heat treatment at $900^{\circ} \mathrm{C}$ for $1 \mathrm{~h}$ is presented in Figure 7. It is observed that the indirect mechanosynthesis process allows one to obtain the main constituents of the clinker $\left(\mathrm{C}_{3} \mathrm{~A}, \mathrm{C}_{2} \mathrm{~S}, \mathrm{C}_{3} \mathrm{~S}, \mathrm{C}_{4} \mathrm{AF}\right)$. 


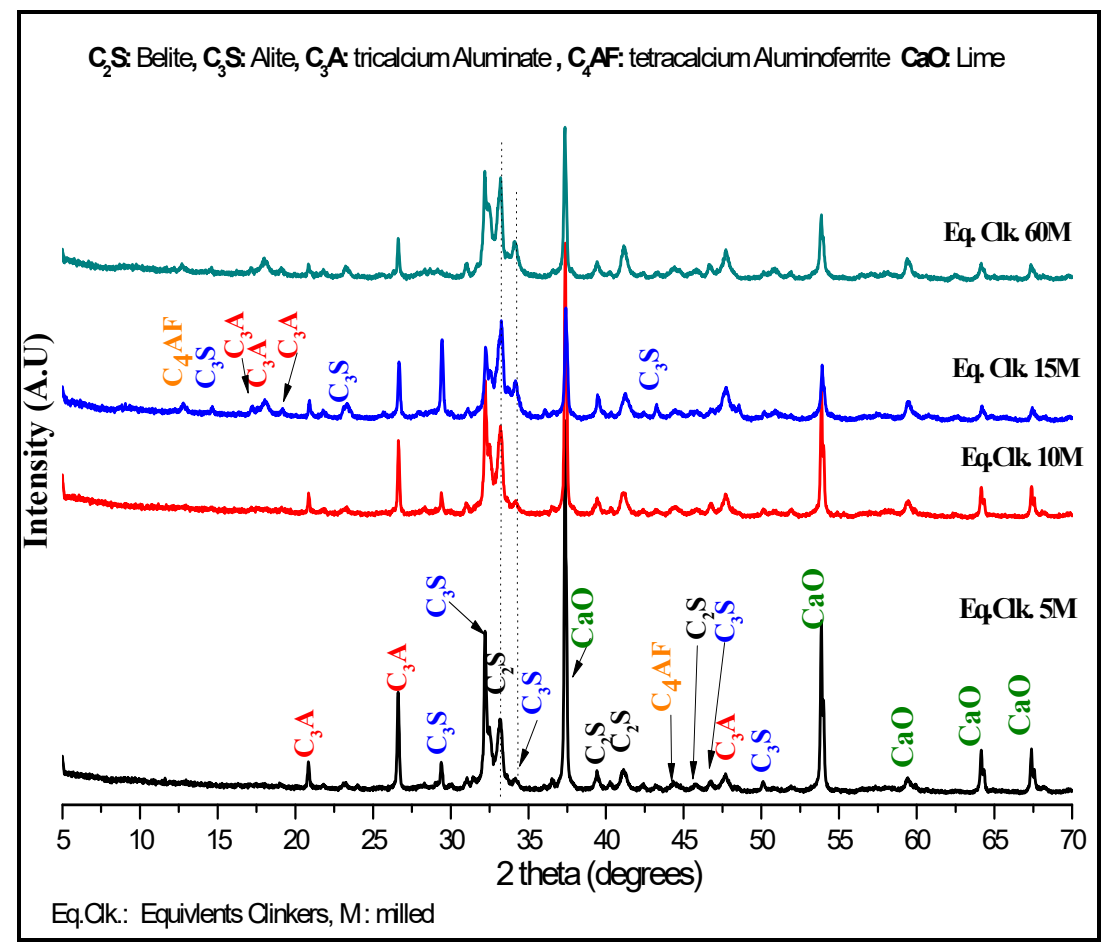

Figure 7. X-ray diffraction patterns of the different clinkers produced by mechanosynthesis.

Peaks of a $\mathrm{C}_{3} \mathrm{~A}$ (tricalcium aluminate $\mathrm{Ca}_{3} \mathrm{Al}_{2} \mathrm{O}_{6}$ ) structure have been found in the positions $2 \theta$ : $20.97^{\circ}(230), 26.76^{\circ}(421), 47.66^{\circ}(800)$ in all X-ray diffraction patterns of the equivalent clinkers (eq. clk.). In addition, the additional peaks are identified in the $2 \theta$ positions $14.20^{\circ}(211), 17.42^{\circ}(221)$, $19.29^{\circ}$ (3 1 1) for the mechanically activated eq. clk. of 15 and $60 \mathrm{~min}$ and $1 \mathrm{~h}$ of heating at $900{ }^{\circ} \mathrm{C}$.

Concerning peaks of an Alite $\mathrm{C}_{3} \mathrm{~S}$ (tricalcium silicate $\mathrm{Ca}_{3} \mathrm{SiO}_{5}$ ) structure, they have been found for all X-ray diffraction patterns in different $2 \theta$ positions: $29.42^{\circ}(32 \overline{2})$ (not found in eq. clk. $60 \mathrm{~min}$ ), $30.07^{\circ}(602), 43.07^{\circ}(92 \overline{4}), 46.82^{\circ}(42 \overline{2}), 50.01^{\circ}$ (3 2 2). For the eq. clk. $15 \mathrm{M}$ and $60 \mathrm{M}$, some additional

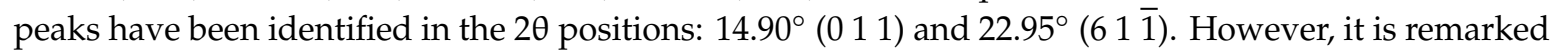
that the intensity of the peak at $2 \theta 29.42^{\circ}$ is higher with a longer milling time except for a milling duration of $60 \mathrm{~min}$.

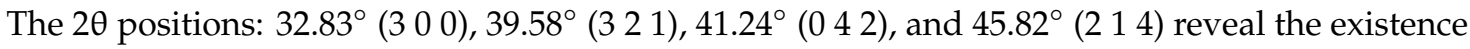
of peaks of Belite $\mathrm{C}_{2} \mathrm{~S}$ (dicalcium silicate $\mathrm{Ca}_{2} \mathrm{SiO}_{4}$ ) with the higher intensities for longer milling time.

It is noticed that the presence of calcium oxide $(\mathrm{CaO})$ with a cubic structure in all equivalent clinkers produced by indirect mechanosynthesis is observed. Several peaks of $\mathrm{CaO}$ cubic structure are identified in the $2 \theta$ positions: $37.38^{\circ}(200), 53.90^{\circ}(220), 64.21^{\circ}(311), 67.43^{\circ}$ (2 22 ). Additionally, it is remarked that the lower the intensity peaks, the higher the milling time. Using TOPAS software in order to quantify the amount of $\mathrm{CaO}$, we found $15 \%, 13 \%, 11 \%$ and $9 \%$ for $5,10,15$ and $60 \mathrm{~min}$ of milling, respectively. It is observed that the lower the $\mathrm{CaO}$ structure, the higher the milling time. It is noted that the main objective of this study is to show the feasibility of indirect mechanosynthesis for obtaining the different constituents of clinker $\left(\mathrm{C}_{2} \mathrm{~S}, \mathrm{C}_{3} \mathrm{~S}, \mathrm{C}_{3} \mathrm{~A}\right.$, and $\left.\mathrm{C}_{4} \mathrm{AF}\right)$ with the $(\mathrm{LS} / \mathrm{C})$ mixture.

To understand the evolution of calcium oxide versus milling time, the evolutions of the lattice parameter, crystallite size, and lattice strain by using instrumental position $2 \theta$ and width of the X-ray diffraction peaks are followed.

Figure 8a presents the change of lattice parameter versus milling time for calcium oxide formation. 


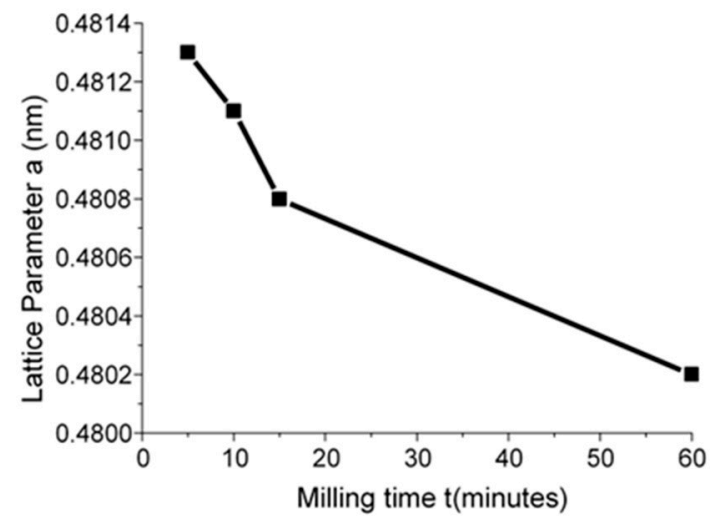

(a)

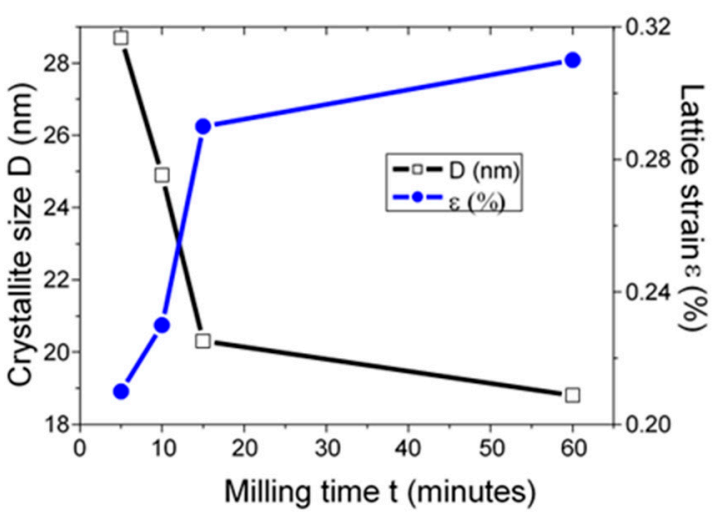

(b)

Figure 8. Evolution at $900{ }^{\circ} \mathrm{C}$ of $\mathrm{CaO}$ versus milling time $\mathrm{t}$ (minutes) of: (a) lattice parameter (nm), (b) crystallite size and lattice strain.

It is observed that the lower the lattice parameter (a) (nm), the higher the milling time from $0.4813 \pm 0.0001 \mathrm{~nm}$ at $5 \mathrm{~min}$ of milling to $0.4802 \pm 0.0001 \mathrm{~nm}$. The evolution of crystallite size and the lattice strain of calcium oxide formation versus the milling time are shown in Figure $8 \mathrm{~b}$. It has been found that the lower crystallite, the higher the lattice strain with the higher milling time. The decrease in crystallite size value is from $28.7 \pm 1.1 \mathrm{~nm}$ at $5 \mathrm{~min}$ of milling to $18.8 \pm 1.1 \mathrm{~nm}$ at $60 \mathrm{~min}$ of milling. The increase in lattice strain value is from $0.21 \pm 0.01 \%$ at $5 \mathrm{~min}$ of milling to $0.31 \pm 0.01 \%$ at $60 \mathrm{~min}$ of milling.

XRD pattern comparison between the equivalent clinker and the conventional clinker obtained by calcination or clinkerization from VICAT cited in our reference [42] is shown in Figure 9.

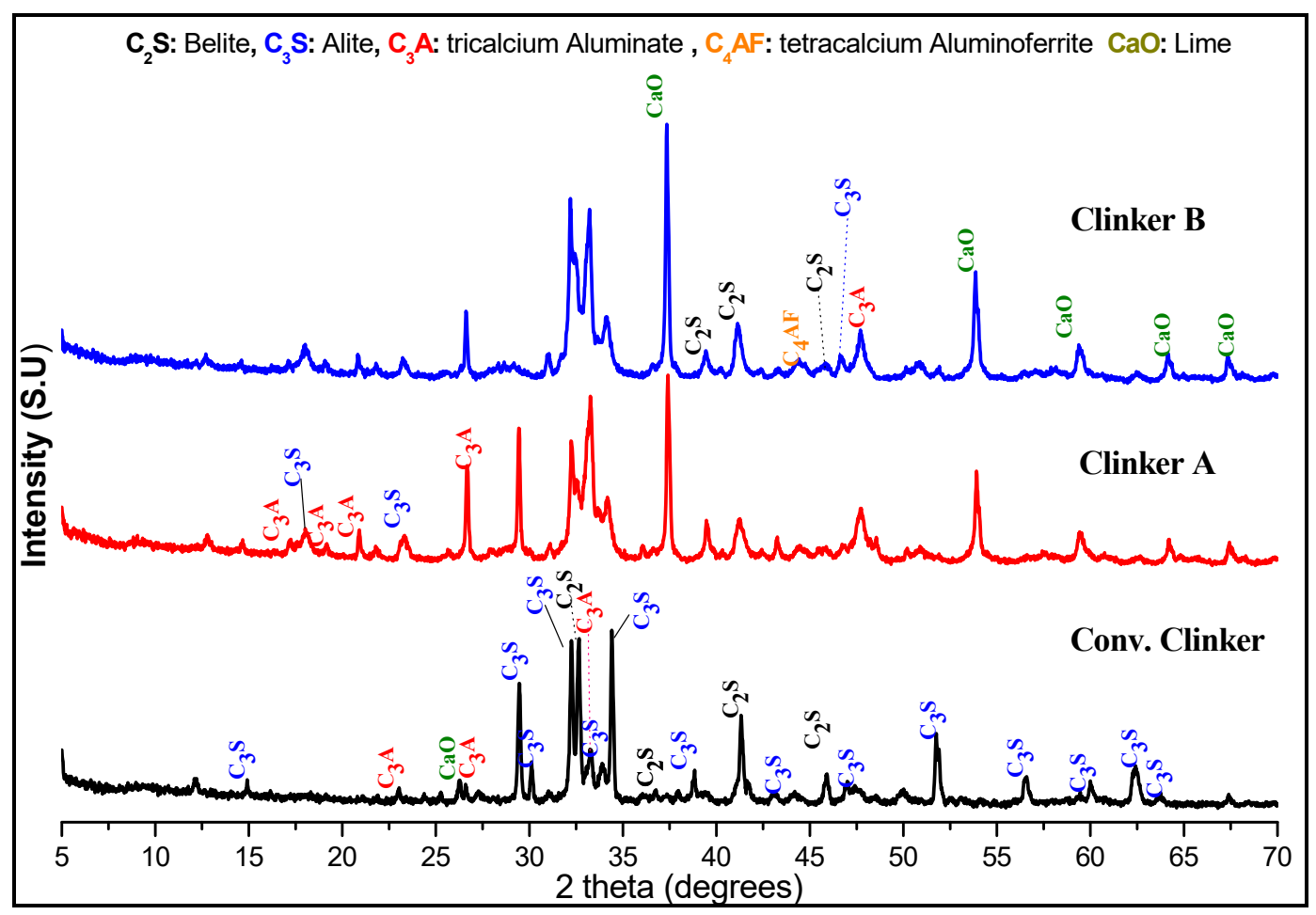

Figure 9. X-ray diffraction patterns of clinker A and B produced by mechanosynthesis versus conventional clinker. 
The X-ray diffraction patterns of conventional clinker from VICAT (Conv clinker), equivalent clinker $15 \mathrm{~min}$ of milling $+1 \mathrm{~h}$ at $900{ }^{\circ} \mathrm{C}$ of heating (clinker A) and equivalent clinker $60 \mathrm{~min}$ of milling $+1 \mathrm{~h}$ at $900{ }^{\circ} \mathrm{C}$ of heating (clinker B) are presented. It is observed that with indirect mechanosynthesis, different crystalized phases, such as alite $\left(C_{3} S\right)$, belite $\left(C_{2} S\right)$, aluminate tricalcium $\left(\mathrm{C}_{3} \mathrm{~A}\right)$, and tetracalcium aluminoferrite $\left(\mathrm{C}_{4} \mathrm{AF}\right)$ at heat treatment of $900^{\circ} \mathrm{C}$, are produced.

Generally, clinkers are manufactured by heating a mixture of limestone and clay, or similar bulk materials of similar composition and adequate reactivity, to a final temperature of about $1450{ }^{\circ} \mathrm{C}$. They contain $55-65 \%$ of the Alite. It is the most important constituent of all clinkers, the Alite; $\mathrm{C}_{3} \mathrm{~S}$ is tricalcium silicate $\left(\mathrm{Ca}_{3} \mathrm{SiO}_{5}\right)$ and formed between $1300-1450{ }^{\circ} \mathrm{C}$. Belite $\mathrm{C}_{2} \mathrm{~S}$ constitutes $15-30 \%$ of normal clinkers. It is obtained between 1000 and $1300{ }^{\circ} \mathrm{C}$ for normal clinkers. For tricalcium aluminate, $\mathrm{C}_{3} \mathrm{~A}\left(\mathrm{Ca}_{3} \mathrm{Al}_{2} \mathrm{O}_{6}\right)$ constitutes $8-12 \%$ of most normal clinkers. The tricalcium aluminate $\mathrm{C}_{3} \mathrm{~A}$ is obtained after the formation of the liquid phase for temperatures between 1200 and $1400{ }^{\circ} \mathrm{C}$ and crystallizing from the melt by the fast air cooling. Tetracalcium aluminoferrite $\mathrm{C}_{4} \mathrm{AF}\left(\mathrm{Ca}_{2} \mathrm{AlFeO}_{5}\right)$ makes up $5-15 \%$ of normal clinkers. It is formed at $1200-1400{ }^{\circ} \mathrm{C}$ and after an air cooling $[1,5,43]$.

\subsubsection{FTIR}

For the purpose of verifying and confirming the presence of $\mathrm{C}_{2} \mathrm{~S}, \mathrm{C}_{3} \mathrm{~S}, \mathrm{C}_{3} \mathrm{~A}$, and $\mathrm{C}_{4} \mathrm{AF}$, FTIR spectroscopy analysis data are given in Figure 10 and Table 2.

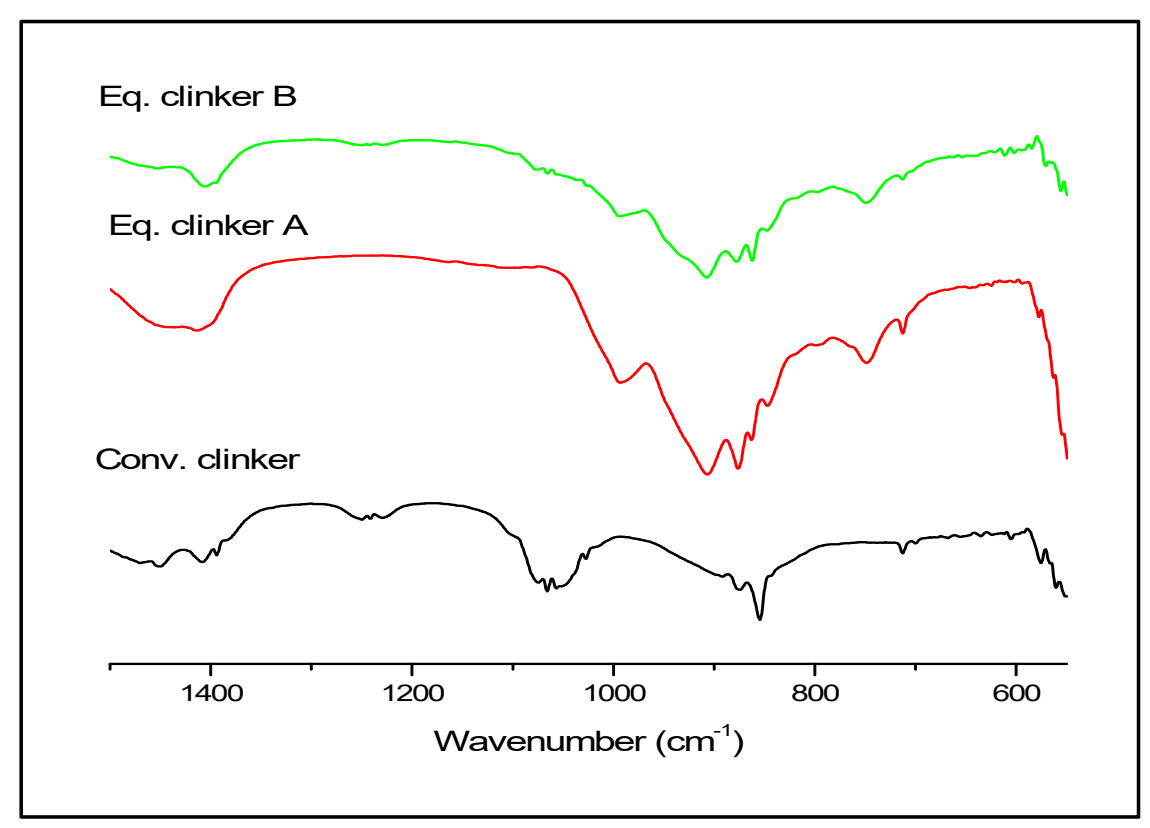

Figure 10. FTIR spectra of the conventional clinker and the clinkers A and B produced by mechanosynthesis.

Table 2. Assignment of FTIR peaks of clinkers.

\begin{tabular}{cc}
\hline Crystalline Phases & Wavenumber $\left(\mathbf{c m}^{-\mathbf{1}}\right)$ \\
\hline $\mathrm{B}_{-} \mathrm{C}_{2} \mathrm{~S}_{\text {ou }} \mathrm{C}_{3} \mathrm{~S}(\mathrm{Si}-\mathrm{O})$ & $846,912,992,1025,1025,1250$ \\
$\mathrm{CaCO}_{3}(\mathrm{C}-\mathrm{O})$ & $712,880,1400,1450$ \\
$\mathrm{C}_{3} \mathrm{~A}(\mathrm{Al}-\mathrm{O})$ & 861 \\
$\mathrm{C}_{4} \mathrm{AF}(\mathrm{Fe}-\mathrm{O})$ & 700 \\
\hline
\end{tabular}

The presence of some compounds found in the X-ray diffraction, such as the $\mathrm{B}_{-} \mathrm{C}_{2} \mathrm{~S}$ or $\mathrm{C}_{3} \mathrm{~S}$ by the absorption band Si-O at 992, 912, and $846 \mathrm{~cm}^{-1}$ for the two equivalent clinkers, $\mathrm{A}$ and $\mathrm{B}$, is confirmed. Besides, the absorption band Si-O for the conventional clinker is found at $1025 \mathrm{~cm}^{-1}$ [44,45]. The width band between 1360 and $1568 \mathrm{~cm}^{-1}$ can be related to calcium carbonate (C-O) and the absorption band at $876 \mathrm{~cm}^{-1}$ is observed only in two patterns of the two equivalent clinkers, $\mathrm{A}$ and $\mathrm{B}$, whereas the band 
at $712 \mathrm{~cm}^{-1}$ is observed in three patterns. Concerning $\mathrm{C}_{3} \mathrm{~A}$ identification, we observed an adsorption band (Al-O) at $861 \mathrm{~cm}^{-1}$ in two patterns of the equivalent clinkers, $\mathrm{A}$ and $\mathrm{B}$. Additionally, for the $\mathrm{C}_{4} \mathrm{AF}$, a band (Fe-O) at $700 \mathrm{~cm}^{-1}$ is found and only observed in the conventional clinker [44,45]. It is noticed that more bands are cited in our reference [42].

\subsubsection{Granulometry}

To study the granularity and morphology of different powders, laser granular and SEM are used. For raw limestone, raw clay, clinker A and clinker B powders, the particle size distribution (PSD) is shown in Figure 11a,b.

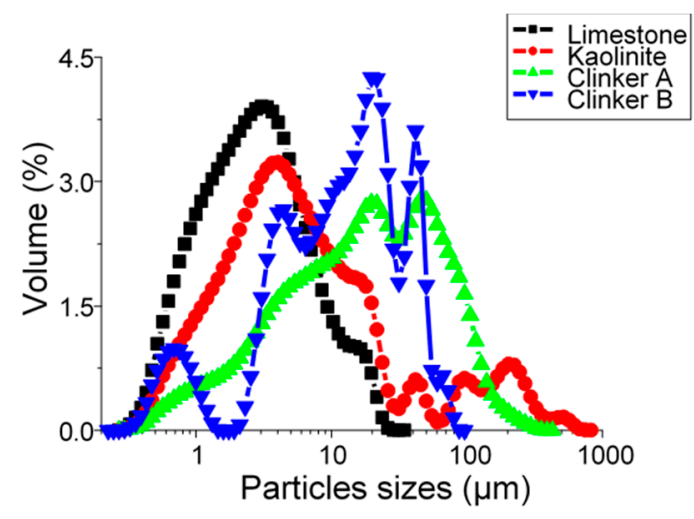

(a)

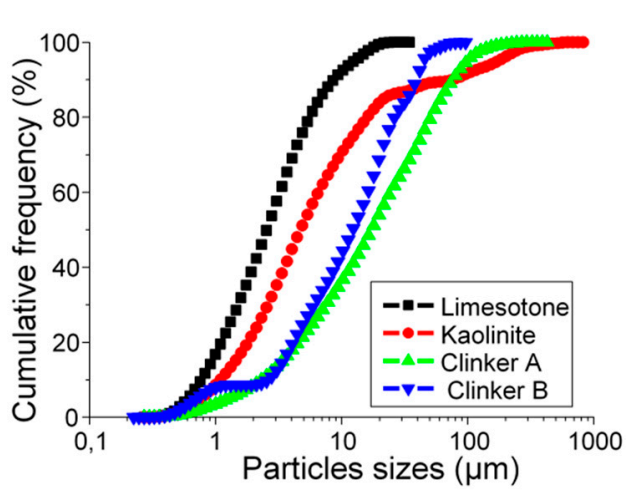

(b)

Figure 11. Particle size distribution analysis of raw limestone, raw kaolinite, clinker A and clinker B powders: (a) volume (\%), (b) cumulative volume (\%).

In Figure 11a, it is observed that the raw limestone has modal distribution with maximum peak found at $3.4 \mu \mathrm{m}$. Raw kaolinite has a multimodal distribution with four particle size ranges. The first particle size range is meaningfully distinct with a large volume corresponding to the fine particle population with typical sizes between $0.3 \mu \mathrm{m}$ and $28.7 \mu \mathrm{m}$ and a maximum peak found at $4 \mu \mathrm{m}$. The second range is between $31.5 \mu \mathrm{m}$ and $60.5 \mu \mathrm{m}$ with a maximum peak at $41.5 \mu \mathrm{m}$. The third range refers to particle sizes from $66.5 \mu \mathrm{m}$ to $140.1 \mu \mathrm{m}$ and with a maximum peak at $96.5 \mu \mathrm{m}$. The last particle size range is recorded between $140.3 \mu \mathrm{m}$ and $460 \mu \mathrm{m}$ with a maximum peak at $223.4 \mu \mathrm{m}$. For both raw materials, limestone and kaolinite, the fine particles are predominating. In the literature, the particle size distribution of raw limestone is reported to have unimodal distribution [46] and raw kaolinite (kaolin) is reported to have unimodal, bimodal, and multimodal distribution [14].

Concerning clinker A and clinker B particle size distributions, it has been found that clinker A has a bimodal distribution with the first maximum peak at $19.8 \mu \mathrm{m}$ and the second maximum peak at $50.3 \mu \mathrm{m}$, whereas it is has been remarked that clinker B has multimodal distribution with four particle size ranges. The first particle size range corresponds to the fine particle population with typical sizes between $0.3 \mu \mathrm{m}$ and $1.5 \mu \mathrm{m}$ and a maximum peak found at $0.7 \mu \mathrm{m}$. The second range is between $1.9 \mu \mathrm{m}$ and $6.5 \mu \mathrm{m}$ with a maximum peak at $4.5 \mu \mathrm{m}$. The third range is bounded from $6.5 \mu \mathrm{m}$ to $31.5 \mu \mathrm{m}$ and with a maximum peak at $21.7 \mu \mathrm{m}$. The fourth particle size range is recorded between $31.5 \mu \mathrm{m}$ and $88 \mu \mathrm{m}$ with a maximum peak at $41.7 \mu \mathrm{m}$. The presence of a multimodal distribution of clinker B can be attributed to the long milling time $(60 \mathrm{~min})$ in comparison to clinker A. According to Figure 11b, concerning the particle size distribution cumulative volume, D10, D50, and D90 values of limestone, kaolinite, clinker A and clinker B are summarized in Table 3. 
Table 3. Median particle sizes: D10\%, D50\% and D90\% of raw limestone, raw kaolinite, clinker A and clinker B powders.

\begin{tabular}{cccc}
\hline Samples & D10 $(\boldsymbol{\mu m})$ & D50 $(\mu \mathrm{m})$ & D90 $(\mu \mathrm{m})$ \\
\hline Limestone & 0.8 & 2.6 & 9.1 \\
Kaolinite & 1.0 & 4.6 & 78.2 \\
Clinker A & 2.4 & 17.5 & 79.7 \\
Clinker B & 2.6 & 11.9 & 40.3 \\
\hline
\end{tabular}

\subsubsection{SEM}

Figure 12a-d present SEM micrographs of raw limestone, kaolinite, clinker A and clinker B powders.

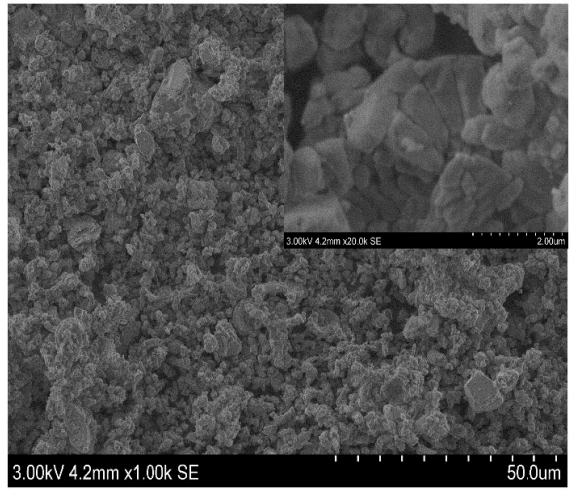

(a)

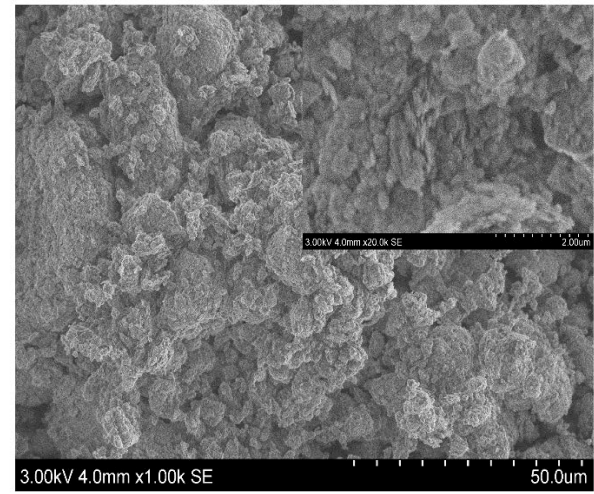

(c)

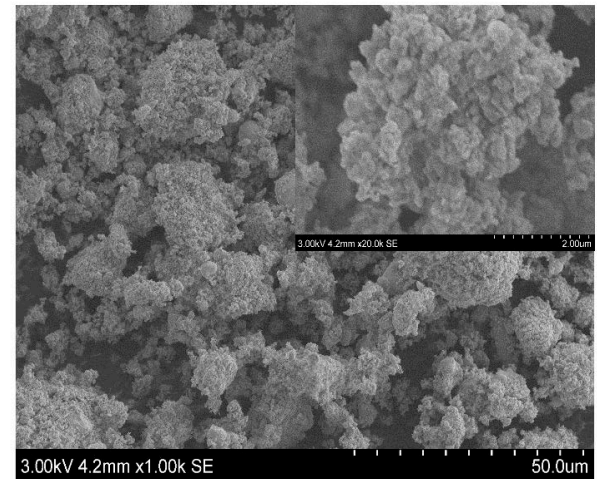

(b)

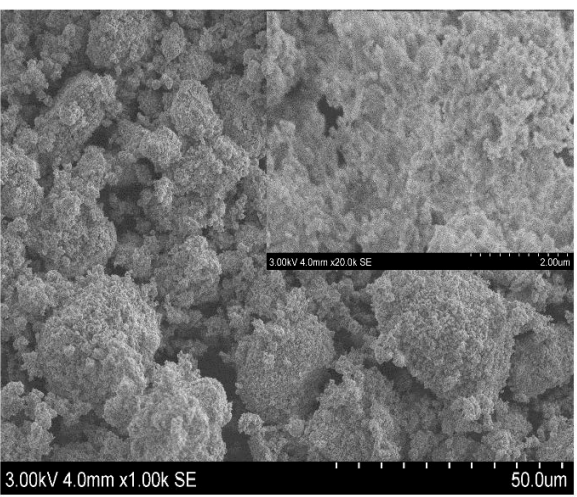

(d)

Figure 12. SEM images of: (a) raw limestone, (b) raw kaolinite, (c) clinker A, (d) clinker B.

The morphology of raw limestone powder (Figure 12a) is irregular with different small particle magnifications. In addition, it can be seen through particle magnification, stacks of rhombohedral crystals, which are found to be equally distant from one another, forming these small aggregates with the average particle size estimated from SEM pictures to be $3 \mu \mathrm{m}$. This result is in concordance with the particle size distribution of limestone.

The morphology of the raw kaolinite is shown in Figure 12b. The particles mostly form stacks and flat particles with irregular shapes. Additionally, different particle sizes can be distinguished, which explains the presence of a multimodal particle distribution with four typical populations.

The morphology of clinker A and clinker B powders (Figure 12c,d) is very similar where the agglomeration of the particles with irregular shapes are observed. Notably, most of the particles have 
roughhouse surfaces. The average particle size found from different SEM pictures is $20 \mu \mathrm{m}$ and $17 \mu \mathrm{m}$ for clinker A and clinker B, respectively.

\section{Conclusions}

In this work, the effect on the structure of the limestone/clay (kaolinite) mixture versus different temperature treatments $\left(400,600\right.$, and $\left.900{ }^{\circ} \mathrm{C}\right)$ for $1 \mathrm{~h}$, milling time $(5,10,15$ and $60 \mathrm{~min})$ and indirect mechanosynthesis process is investigated. Concerning heat treatment, the structural study shows the disappearance of all kaolinite peaks from $400{ }^{\circ} \mathrm{C}$ with the formation of metakaolinite structure. In addition, there is the disappearance of some calcite peaks and the apparition of calcium oxide peaks at $900{ }^{\circ} \mathrm{C}$.

Concerning milling time effect on structure, we observed peak enlargement of quartz and calcite as function of milling time.

For the indirect mechanosynthesis process, the formation of the main constituents of the clinkers $\left(\mathrm{C}_{3} \mathrm{~A}, \mathrm{C}_{2} \mathrm{~S}, \mathrm{C}_{3} \mathrm{~S}, \mathrm{C}_{4} \mathrm{AF}\right)$ at $900{ }^{\circ} \mathrm{C}$ is shown.

Indirect mechanosynthesis is a technique that can achieve the production of clinkers at $900{ }^{\circ} \mathrm{C}$ and less, whereas the classical technique for normal clinker is obtained at $1450{ }^{\circ} \mathrm{C}$ of calcination.

Author Contributions: 50\% R.H., 50\% O.B. Conceptualization, R.H. and O.B.; methodology, O.B.; software R.H. and O.B.; validation, R.H. and O.B.; formal analysis, O.B.; investigation, O.B.; resources, O.B.; data curation, R.H. and O.B; writing - original draft preparation, O.B.; writing —review and editing, R.H.; visualization, R.H. and O.B.; supervision, R.H.; project administration, R.H. and O.B.; funding acquisition, R.H. (ESTP Foundation). All authors have read and agreed to the published version of the manuscript.

Funding: This research received from ESTP Foundation funding and no external funding.

Acknowledgments: We want to thank Margareta Walferdein from IRC/ESTP Cachan for her assistance in the XRD. We want also to thank Marc Bonnet from LMT/ENS Paris-Saclay for his time and expertise in the SEM. Finally, we want to thank ESTP foundation for funding.

Conflicts of Interest: The authors declare no conflict of interest.

\section{References}

1. Kurdowski, W. Cement and Concrete Chemistry; Springer: Dordrecht, The Netherlands, 2013. [CrossRef]

2. IEA. Technology Roadmap_Low-Carbon Transition in the Cement Industry. 2018. Available online: www.wbcsdcement.org (accessed on 5 December 2018).

3. Schneider, M.; Romer, M.; Tschudin, M.; Bolio, H. Sustainable cement production-present and future. Cem. Concr. Res. 2011, 41, 642-650. [CrossRef]

4. Scrivener, K.L. Special Issue-Future Cements Options for the Future of Cement. 2014. Available online: http://www.lc3.ch/wp-content/uploads/2014/09/0851_ICJ_Article.pdf (accessed on 6 March 2019).

5. Gartner, E. Industrially interesting approaches to "low- $\mathrm{CO}_{2}$ " cements. Cem. Concr. Res. 2004, 34, 1489-1498. [CrossRef]

6. Siddique, R.; Khan, M.I. Supplementary Cementing Materials; Springer Science and Business Media: New York, NY, USA, 2011. [CrossRef]

7. Payá, J.; Monzó, J.; Borrachero, M.V.; Peris, E.; González-López, E. Mechanical treatments of fly ashes. Part III: Studies on strength development of ground fly ashes (GFA)_Cement mortars. Cem. Concr. Res. 1997, 27, 1365-1377. [CrossRef]

8. Payá, J.; Monzó, J.; Borrachero, M.V.; Peris-Mora, E.; Amahjour, F. Mechanical treatment of fly ashes-Part IV. Strength development of ground fly ash-cement mortars cured at different temperatures. Cem. Concr. Res. 2000, 30, 543-551. [CrossRef]

9. Behim, M.; Cyr, M.; Clastres, P. Physical and chemical effects of El Hadjar slag used as an additive in cement-based materials. Eur. J. Environ. Civ. Eng. 2011, 15, 1413-1432. [CrossRef]

10. Kourounis, S.; Tsivilis, S.; Tsakiridis, P.E.; Papadimitriou, G.D.; Tsibouki, Z. Properties and hydration of blended cements with steelmaking slag. Cem. Concr. Res. 2007, 37, 815-822. [CrossRef]

11. Scrivener, K.; Martirena, F.; Bishnoi, S.; Maity, S. Calcined clay limestone cements (LC3). Cem. Concr. Res. 2018, 114, 49-56. [CrossRef] 
12. Bouchenafa, O.; Hamzaoui, R.; Bennabi, A.; Colin, J. PCA effect on structure of fly ashes and slag obtained by mechanosynthesis. Applications: Mechanical performance of substituted paste CEMI + 50\% slag/or fly ashes. Constr. Build. Mater. 2019, 203, 120-133. [CrossRef]

13. Hamzaoui, R.; Muslim, F.; Guessasma, S.; Bennabi, A.; Guillin, J. Structural and thermal behavior of proclay kaolinite using high energy ball milling process. Powder Technol. 2015, 271, 228-237. [CrossRef]

14. Hamzaoui, R.; Bouchenafa, O.; Ben Maaouia, O.; Guessasma, S. Mechanosynthesis for kaolinite activation: The impact of the substitution on the mechanical performances of mortar. Powder Technol. 2019, 355, 340-348.

15. Oleszak, D.; Kaszuwara, W.; Wojciechowski, S. Mechanosynthesis of Nd-Fe-B alloys. J. Mater. Sci. 1996, 31 , 5725-5729. [CrossRef]

16. Gaffet, E.; Le Caër, G. Mechanical Milling. In Nanomaterials and Nanochemistry; Bréchignac, C., Houdy, P., Lahmani, M., Eds.; Springer Science and Business Media: New York, NY, USA, 2008; pp. 455-471. [CrossRef]

17. Benjamin, J.S.; Volin, T.E. The mechanism of mechanical alloying. Metall. Trans. 1974, 5, 1929-1934. Available online: http://journals.cambridge.org/abstract_S0884291400020732 (accessed on 11 October 2018).

18. Shoji, K.; Austin, L.G. A model for Batch Rod Milling. Powder Technol. 1974, 10, $29-35$.

19. El-Eskandarany, M.S.; Aoki, K.; Suzuki, K. Rod milling for solid-state formation of Al30Ta70 amorphous alloy powder. J. Less Common Met. 1990, 167, 113-118. [CrossRef]

20. El-Eskandarany, M.S. Mechanical Alloying, Nanotechnology, Materials Science and Powder Metallurgy, 2nd ed.; William Andrew: Norwich, NY, USA, 2015. [CrossRef]

21. Birringer, R. Nanocrystalline materials. Mater. Sci. Eng. A 1989, 117, 33-43. [CrossRef]

22. Meyers, M.A.; Mishra, A.; Benson, D.J. Mechanical properties of nanocrystalline materials. Prog. Mater. Sci. 2006, 51, 427-556. [CrossRef]

23. Gleiter, H. Nanocrystalline materials. Prog. Mater. Sci. 1989, 33, 223-315. [CrossRef]

24. Suryanarayana, C. Mechanical Alloying and Milling; Marcel Dekker: New York, NY, USA, 2004; Available online: https://www.crcpress.com/Mechanical-Alloying-And-Milling/Suryanarayana/p/book/9780824741037 (accessed on 22 January 2019).

25. Benjamin, J.S. Dispersion strengthened superalloys by mechanical alloying. Metall. Trans. 1970, 1, $2943-2951$. [CrossRef]

26. Hamzaoui, R. Mécanosynthèse et Propriétés Magnétiques D'alliages Fe-Ni; Université de Technologie de Belfort-Montbeliard: Belfort, France, 2004.

27. Malhouroux-Gaffet, N.; Gaffet, E. Solid state reaction induced by post-milling annealing in the FeSi system. J. Alloys Compd. 1993, 198, 143-154. [CrossRef]

28. Gaffet, E.; Malhouroux, N.; Abdellaoui, M. Far from equilibrium phase transition induced by solid-state reaction in the FeSi system. J. Alloys Compd. 1993, 194, 339-360. [CrossRef]

29. Öksüz, K.E.; Apaydın, F.; Bozdağ, A.E.; Çevik, M.; Özer, A. Phase and Morphological Evaluation of Mechanically Activated Sintered YAG Powders. Procedia Mater. Sci. 2015, 11, 44-48. [CrossRef]

30. Farnè, G.; Ricciardiello, F.G.; Podda, L.K.; Minichelli, D. Innovative milling of ceramic powders: Influence on sintering zirconia alloys. J. Eur. Ceram. Soc. 1999, 19, 347-353. [CrossRef]

31. Zeghmati, M.; Duverger, E.; Gaffet, E. Mechanically Activated Self-Propagating High Temperature Synthesis in the Fe-Al System. In Proceedings of the CANCAM, 15th Canadian Congress of Applied Mechanics, Victoria, BC, Canada, 28 May-1 June 1995; Tabarrock, B., Dost, S., Eds.; University of Victoria: Victoria, BC, Canada, 1995; Volume 2, pp. 952-953.

32. Zhang, W.; Wang, H.; Jun, H.; Yu, M.; Wang, F.; Zhou, L.; Yu, G. Acceleration and mechanistic studies of the mechanochemical dechlorination of HCB with iron powder and quartz sand. Chem. Eng. J. 2014, 239, 185-191. [CrossRef]

33. Andini, S.; Bolognese, A.; Formisano, D.; Manfra, M.; Montagnaro, F.; Santoro, L. Mechanochemistry of ibuprofen pharmaceutical. Chemosphere 2012, 88, 548-553. [CrossRef]

34. Balaz, P. Applied Mechanochemistry. Mechanochem. Nanosci. Miner. Eng. 2008, 297-405. [CrossRef]

35. Grim, R.E. Clay Mineralogy, 2nd ed.; Mc Graw-Hill: New York, NY, USA, 1968; Available online: https: //trove.nla.gov.au/work/10702146 (accessed on 30 June 2020).

36. Meunier, A. Clays; Springer: Berlin/Heidelberg, Germany, 2005.

37. Piringer, H. Lime Shaft Kilns. In Energy Procedia; Elsevier Ltd.: Amsterdam, The Netherlands, 2017; pp. 75-95. [CrossRef] 
38. Rodriguez-Navarro, C.; Ruiz-Agudo, E.; Luque, A.; Rodriguez-Navarro, A.B.; Ortega-Huertas, M. Thermal decomposition of calcite: Mechanisms of formation and textural evolution of CaO nanocrystals. Am. Mineral. 2009, 94, 578-593. [CrossRef]

39. Kumar, G.S.; Ramakrishnan, A.; Hung, Y.-T. Lime Calcination. In Advanced Physiochemical Treatment Technologies; Humana Press: Totowa, NJ, USA, 2007; pp. 611-633. [CrossRef]

40. Karunadasa, K.S.P.; Manoratne, C.H.; Pitawala, H.M.T.G.A.; Rajapakse, R.M.G. Thermal decomposition of calcium carbonate (calcite polymorph) as examined by in-situ high-temperature $\mathrm{X}$-ray powder diffraction. J. Phys. Chem. Solids 2019, 134, 21-28. [CrossRef]

41. Karunadasa, K.S.P.; Manoratne, C.H.; Pitawala, H.M.T.G.A.; Rajapakse, R.M.G. The composition, unit cell parameters and microstructure of quartz during phase transformation from $\alpha$ to $\beta$ as examined by in-situ high-temperature X-ray powder diffraction. J. Phys. Chem. Solids 2018, 117, 131-138. [CrossRef]

42. Bouchenafa, O.; Hamzaoui, R.; Azem, L.; Bennabi, A.; Colin, J. Manufacturing equivalent Clinker by indirect mechanosynthesis process. In Proceedings of the 1st International Conference on Innovation in Low-Carbon Cement and Concrete Technology, London, UK, 24-26 June 2019; pp. 1-4.

43. Taylor, H.F.W. (Ed.) Cement Chemistry, 2nd ed.; Thomas Telford Publishing: London, UK, 1997. [CrossRef]

44. Hughes, T.L.; Methven, C.M.; Jones, T.G.J.; Pelham, S.E.; Fletcher, P.; Hall, C. Determining cement composition by Fourier transform infrared spectroscopy. Adv. Cem. Based Mater. 1995, 2, 91-104. [CrossRef]

45. Benosman, A.S.; Taibi, H.; Mouli, M.; Belbachir, M. Valorisation de la spectrométrie infrarouge (FTIR) pour l'analyse qualitative de composes des ciments, argiles, et des mélanges ciment/argile. In Communication Science E Technologie; COST: Oran, Algerie, December 2004.

46. Sun, J.; Chen, Z. Influences of limestone powder on the resistance of concretes to the chloride ion penetration and sulfate attack. Powder Technol. 2018, 338, 725-733. [CrossRef]

Publisher's Note: MDPI stays neutral with regard to jurisdictional claims in published maps and institutional affiliations. 